\title{
Targeted industrial poverty alleviation in China's Rural Areas: Evidence From Yulin Township
}

\author{
Chen $\mathrm{Yu}^{*}$ \\ Shenzhen College of International Education, Shenzhen, China
}

\author{
Keywords \\ Poverty alleviation \\ Industrial \\ Targeted \\ Income \\ Received: 8 November 2019 \\ Accepted: 17 January 2020 \\ Published: 13 June 2020
}

\begin{abstract}
The main focus of this research is to briefly introduce the history of poverty alleviation programs in China and focus on investigating targeted industrial poverty alleviation programs in Yulin Township (Mingshui County) and assessing the effectiveness of its methods. The aim of this paper is to present a detailed description of the targeted industrial poverty alleviation program and explain how it differs from other similar programs. The data in this paper comes primarily from the poverty alleviation office in Yulin Township and contains both individual-level and aggregated variables. The main findings highlight that the program is successful in reducing poverty and increasing incomes. Moreover, among the individual measures that comprise the program, the reward for working and transportation subsidy seems to achieve the highest success in increasing incomes for many households. Also, the other measures may be better suited for various segments of the population.
\end{abstract}

(C) 2020 The Author(s). Published by TAF Publishing

\section{INTRODUCTION}

This paper will briefly introduce poverty alleviation in China and investigate Yulin Township as an example. It will also measure the efficiency of different targeted industrial methods in Yulin Township.

The topic of poverty alleviation is important for two reasons. First, poverty alleviation is one of the most important programs of the Chinese government. The Chinese government has set a target of getting out of poverty entirely by the end of 2020. Second and more importantly, Yulin Township was one of the most successful townships in China with respect to poverty eradication. Hence the experience of Yulin Township can be used as an example to help other countries, especially developing countries, to carry out their own poverty alleviation projects.

The paper is organised as follows. First, it describes background including the sources of poverty. Second, it introduces the targeted poverty alleviation programme in Yulin Township. Third, it discusses the data collected from the office in charge of poverty alleviation. Finally, it analyses the programme both in its entirety as well as its individual parts.

\section{Objectives of the Study}

The goal of this paper is to characterise the targeted poverty alleviation project. The paper will explain how it has been carried out and what effects it has brought about. The main focus will be on assessing the efficiency of different targeted industrial poverty alleviation measures.

\section{BACKGROUND}

The British economist Benjamin Seebohm Rowntree (1901, 236) reveals poverty from the perspective of income. He believes that poverty is defined as poverty when the total income is insufficient to meet the minimum living needs. Reducing poverty has become a goal for many governments in developing countries (Dominique, 2019).

Since the founding of new China in 1949, the Chinese government has been devoting efforts to alleviate poverty (Y. Liu, Guo, \& Zhou, 2018). Between 1949 and 1978, China had the largest share of poverty population among devel-

\footnotetext{
* corresponding author: Chen Yu

†email: s19832.chen@stu.scie.com.cn
} 
oping countries. 250 million people lived in poverty, which was $25.97 \%$ of total Chinese population and a quarter of the world's total poverty population. In China, there is close relationship between location and level of poverty (Gustafsson \& Wei, 2000; Kim, 2016). The geographic dimensions of inequality are also significant in China which is a developing country (Hannum, 2003). As illustrated in The Profile of Poor Counties Across the Country 1977-1979, which was published by the Commune Management Bureau, Agriculture Ministry in 1981, between 1979 and 1984, China has experienced its initial stage in carrying out poverty alleviation policies. Particular grants, such as Development Fund for Backward Regions, Sanxi Agricultural Construction Fund and so on were provided to poverty stricken areas by the Ministry of Finance (Luk, 2000). In order to reduce poverty, China has also carried out rural economic reforms, which adopt the production responsibility system (Okpala, Omojuwa, Elenwo, \& Opoko, 2017; Piazza \& Liang, 1998).

In 1984, the Chinese government initiated the development-oriented poverty alleviation program to get rid of poverty by stimulating the local economic development. According to Li, Su, and Liu (2016), in 1994, the Chinese government launched the "8-7 Poverty Reduction Plan", where the numbers refer to 80 million people to be lifted out of poverty in 7 years. 592 counties, which account for $28 \%$ of all county-level administrative units in China, were involved in the programme (Meng, 2013). As reported in China Agricultural Development Report published by Beijing: China Agricultural Publishing House in 2000 , this has successfully reduced the number of poor in China to 30 million in 2000. The huge reduction in such short time is considered as one of the greatest achievements in human development in the twentieth century (Fan, Linxiu, \& Xiaobo, 2004). Then in 2001, The Outline for Poverty Reduction and Development of China's Rural Areas (2001-2010) was introduced (Nima, 2019). In 2011, the "China's Rural Poverty Reduction and Development Compendium (2011-2020)" was issued by The Central Committee of the Communist Party of China and the State Council. It emphasized community-based poverty alleviation by advancing rural development, industrialization and peoples' training. It involved the local governments, market and social organizations as well as the individuals. 14 contiguous poverty-stricken areas were identified in China in 2012. The basic idea of the planning of the contiguous destitute areas was that "regional development promotes poverty alleviation and poverty alleviation boosts regional development", which is the specific embodiment of the organic convergence between regional development and poverty alleviation in the historic transition of China's poverty alleviation and development (Zuo, 2019). In 2014, <Establishing Targeted Poverty Alleviation Working Mechanism and Implementation Plan> has been published by State Council's Office of Poverty Alleviation and Development. The mechanism of targeted poverty alleviation was jointly released, which this paper is going to cover in detail. This could be considered an innovative poverty alleviation theory (Li, 2019), it also indicates a significant transformation of Chinese poverty alleviation policies (Wang, Chen, \& Yan, 2016).

In 2015, the United Nations released the "Millennium Development Goals Report" that showed that China had already achieved the goal of halving the proportion of extremely poor people from 1990 to 2015. In September 2015, world leaders adopted the $<2030$ agenda for sustainable development $>$ at the United Nations headquarters, which takes the elimination of poverty in all its forms as the primary goal, demonstrating the firm determination of the whole world on the road to alleviate poverty. In December 2018, the white paper < Development and Progress of China's Human Rights Cause in the 40 Years of Reform and Opening Up> showed that over the past 40 years, China has relieved more than 850 million people out of poverty and contributed more than $70 \%$ to global poverty reduction.

By the end of 2019, the number of rural poverty population in China decreased to 5.51 million, which accounts for $0.6 \%$ of the total Chinese population. This constitutes a reduction of 11.09 million since the end of 2018 according to the National Bureau of Statistics.

China has kept increasing its investment in poverty alleviation, but the marginal effect of investment in poverty alleviation has been declining. For example, in 2011, a billion RMB of investment in poverty alleviation led to lifting of 8.78 million people out of poverty. However, this number has been steadily declining, and ultimately fell below 1 million in 2016 and 2017 (M. Liu, Feng, Wang, \& Qiu, 2020). In this paper, I focus on Yulin Township as an example of a successful poverty alleviation programme. Total area of Yulin Township is 40093 acres, including 17792 acres of arable land, 3624 acres of woodland and 6095 acres of grassland. $55 \%$ of arable land, woodland and grassland is alkali soil. Yulin Township is located in Mingshui County which was identified as a national "poverty county" in 1990, one of the provincial poverty alleviation key counties in 2002 and one of the "ten weak counties" in 2003. What make it even more interesting is that Yulin Township was the township with highest percentage of poverty population 
in Mingshui County and its 7 incorporated villages used to all be poverty villages. However, Yulin Township has become one of the most successful townships with regards to poverty alleviation, and by 2019 there were no poor villages left in the township.

Poverty alleviation in Yulin Township experienced 3 main phases. Before 2014, it carried out poverty alleviation methods which were identical across China. Between 2014 and 2016, Yulin Township carried out the so-called targeted poverty alleviation. This meant using scientific and effective procedures, in view of the situation of different poor areas and the situation of different poor farmers, to implement accurate identification, accurate assistance and precise management. After 2016, the idea of a special method - targeted industrial poverty alleviation - was carried out. The local government listed 10 industrial poverty alleviation methods based on Yulin Township's situation. The poverty households could choose between 1 and 7 methods from a menu of options based on the household's preference and ability. The difference between targeted poverty alleviation and targeted industrial poverty alleviation is that the first one is an overall idea that was carried out in all parts in China and the second one is the special measure specifically designed for and carried out by Yulin Township.

The causes of poverty is widely discussed by various economists. Malthus (1980), a British economist, put forward the theory of population growth from the perspective of demography. He believes that the population growth will lead to the decline in social labour productivity, land resources, food supply chain and total social demand, which will lead to economic recession and poverty. In "looking at development with freedom", Sen (2001), an Indian economist, gives a new interpretation of the phenomenon of poverty and its causes from the perspective of deprivation of feasible ability. He links the lack of substantive freedom with economic poverty, and thinks that poverty is not only low income, but also must be regarded as the deprivation of basic feasible ability, because low income can be the main reason for one's sexual deprivation. From the perspective of economics, Myrdal (1991) proposed that the cause of poverty lies in the unreasonable economic system, and social and economic inequality is the main cause of poverty in a country. While in $<$ Poverty Eradication and Social Integration: the Position of the UK>, Short (2002) believes poverty was attributed to the marginalization of the rights of social members. In the recent study, Y. Liu, Liu, and Zhou (2017) believe that in rural China, illness is the greatest contributor to current poverty.

There are a number of sources of poverty in Yulin Township both at the aggregated and the individual level, which are listed below.

\section{Aggregated Level \\ Shortage of natural resources}

The only resources that Yulin Township owns are land resources, water resources, plant resources and wild animal resources. Their amounts have decreased as a result of human activities. It does not have any underground resources like minerals, metal or fossil fuels.

\section{Poor soil quality}

As mentioned above, the total area of land is 40093 acres, but 15131 acres are alkali soil which is not suitable for planting. The output of normal land is 50 kilogram per acre, while the output of alkali land is only 16.7 kilogram per acre.

\section{Frequent natural disasters}

Because of the geographic location, there often occur severe natural disasters such as water logging, drought, intense snowfall and crop disease. These natural disasters heavily reduce the yield in Yulin Township and lead to decreased incomes of the farmers.

\section{Only one natural growth cycle}

Yulin Township is located in the north-eastern part of China. In winter, the temperature can reach -30oC. As a result, it is impossible to grow crops in winter and farmers can only plant crops once a year. They do not have any work to do during the rest of the year.

\section{Inconvenient transportation}

Roads in Yulin Township used to be made of soil. Nowadays, they have been transformed into cement roads which could be easier to drive on. However, there is no train between Yulin Township and other cities.

\section{Lack of information}

In the past, residences in Yulin Township could not obtain access to the internet. Thus they could not receive information from out of the county or extend their knowledge about agriculture. Moreover, they did not have the ability to sell their crops through the internet. Poor households are lack of incentive to participate in poverty alleviation and cooperate with local government when they have limited access to information (Zhang et al., 2019).

\section{Individual Level}

By the end of 2014, Yulin Township officially started registration of poverty households. It had 1169 poverty households at that time. These households had different reasons 
of poverty including the following:

\section{IIlness}

Some members of a household may have illnesses, especially chronic conditions such as cancer. In such case all income of the household was used on the therapy on the member and it proved impossible to save. This factor is estimated be the lead cause for 702 poverty households.

\section{Disability}

If a member of the household, especially the young male member, is disabled, he could not do agricultural or other types of work. Therefore, the household is short of labour and it does not receive any wages. For 139 poverty households this has been the main cause.

\section{Education}

If a family's child is receiving education out of the county, for instance study at a university in another city, the tuition and cost of living will be really expensive for their family. Sometimes almost all of their income will be spent on the child. This factor resulted in 16 poverty households.

\section{Ideological problems}

Some farmers were quite lazy and might even not have wanted to become wealthier. They did not desire to receive help from the local government. For example, a household kept living in their broken house even after the government has built a house made of steel for them.

\section{Annoying habits}

A number of farmers had bad habits, such as alcoholism, smoking and gambling. These habits are costly and difficult to get rid of. Most of the income in such households, as well as their savings, are often spent on the annoying habits.

\section{Targeted Industrial Poverty Alleviation}

Targeted industrial poverty alleviation is a special method carried out by the Yulin Township government. It is called 'industrial poverty menu' by the local officers and residents. It means listing 10 methods that can be used to alleviate poverty, from which the poverty households can make choices of between 1 and 7 options. These 10 methods, which are based on different industries, are listed below.

\section{Crops order planting}

Various organization and individuals in the society customise agricultural products and special agricultural products planted by the poverty households on their own land. When crops mature, the communities will buy what they have ordered with a price higher than the market price, thereby providing the income to the poverty household.

\section{Customizing dried vegetables}

Corporations order dried vegetables such as dried potatoes, carrots and beans. The poverty households will dry some of the vegetables which they plant. In autumn, these dried vegetables will be bought by the corporations.

\section{PV electricity generation}

Poverty is linked closely with the access to energy ( $\mathrm{Xu}$, Zhang, \& Shi, 2019). In Yulin Township, some corporations have invested in the facilities used to generate electricity and these facilities were put on the vacant land in Yulin Township. The electricity generated is transmitted to the national grid. The reward is divided by the corporation and the county. After that, Yulin Township will distribute the reward to the poverty households who are above 60 years old and those who are disabled.

\section{Pigs raising assistance}

Poverty households raising 4 or more pigs will be rewarded with $800 \mathrm{RMB}$, and poor households raising 8 or more pigs will be rewarded with 1200 RMB. Every sow raised by poverty households will be rewarded with $200 \mathrm{RMB}$. If it farrows before October 1 , an additional bonus of $300 \mathrm{RMB}$ will be rewarded.

\section{Geese raising assistance}

Poverty households can get 4 RMB when they raise one goose. Poverty households that raise more than 20 white geese can get a subsidy of 20 RMB. Also, they can be rewarded 2 RMB for each additional goose.

\section{Sheep raising assistance}

Poverty households that raise 2 or more sheep will be rewarded with $750 \mathrm{RMB}$, those that raise 4 or more sheep will be rewarded with $1150 \mathrm{RMB}$, and those raise 8 or more sheep will be rewarded with 1750 RMB. If $1-3$ ewe lambs are born, the households will be additionally rewarded with $200 \mathrm{RMB}$. If the number is 4-6, the reward will be $300 \mathrm{RMB}$ and $400 \mathrm{RMB}$ will be rewarded if the number of ewe lambs is over 7 .

\section{Reward for working in and out of the township}

If the wage income of a poverty household exceeds 6,000 RMB, the extra reward will be 300 RMB. For every 1,000 RMB increase in income, the reward will be increased by 50 RMB. The reward cannot exceed 600 RMB per year. Workers need to provide their labour contract or employment certificate as well as the payroll or pay card bank statement. 


\section{Public service jobs}

Some poverty households who are capable of working will be employed by the local government to complete the work which are beneficial for the county. In 2019, there will be 806 workers in charge of maintaining the forests in the county, with a salary of 3,000 RMB per worker.

\section{Leading and cooperation}

There are several households who are relatively richer and run their own business, for instance a plantation of Pleurotus eryngii. These places will employ poverty household members and offer them adequate wages.

\section{Financial assistance}

Interest-free loans are provided to the poverty households. A total of 750 million RMB in poverty alleviation loans were provided, including 620 million RMB in industrial poverty alleviation loans.

\section{LITURATURE REVIEW}

\section{Orientation of "Anti-Poverty"}

From the perspective of academic development, causes of poverty are widely discussed. Y. Liu et al. (2017), Myrdal (1991), Sen (2001), Short (2002) have all proposed different causes of poverty in their studies. Apart from that, there were first studies on the concept and types of poverty (Nima, 2019; Piazza \& Liang, 1998). It was not until 1968, when the Swedish economist Karl Gunnar Myrdal published <Asian Drama: An Inquiry into the Poverty of Nations>, that he first put forward the anti-poverty theory, used the cumulative causation model to explain the mechanism of the occurrence and development of poverty in developing countries and put forward suggestions on measures against poverty.

\section{Suggestions on Poverty Alleviation Policies}

The author of <Poor Economics>, Abhijit Banerjee and Esther Duflo, investigated the greatest concentration of poor people in 18 countries and regions. And raised a thought-provoking question: "What form of aid is most effective?" The authors also propose solutions such as providing correct information and policy support to the poor as well as changing the beliefs of the poor. Amartya Sen, "the economist who cares most about the poor", published $<$ Poverty and Famines $>$ in 1981. His research shows that only by establishing a social atmosphere of equality and political responsibility, famine can be avoided and poverty could be eliminated.

\section{History of Poverty Alleviation in China}

There are a large number of studies on the development and history of poverty alleviation policies in China. The studies by Fan et al. (2004), Luk (2000), Meng (2013) show poverty alleviation policies in different eras in China from 1949 till now.

\section{Industrial Poverty Alleviation}

As it shows in various studies (Xu et al., 2019), industrial poverty alleviation programmes are considered as one of the most effective measures. Industrial poverty alleviation can change the way of alleviating poverty from "blood transfusion" to "blood making", so as to minimize the risk of returning to poverty (Dominique, 2019).

\section{Targeted Poverty Alleviation}

In China, targeted poverty alleviation was published in 2014 by the State Council. Li et al. (2016), Li (2019), Wang et al. (2016) analysed the mechanism of targeted poverty alleviation and consider it an innovation in poverty alleviation policies which has brought significant improvements.

\section{Difference between this Study and Previous Studies}

Through literature retrieval, the author finds that, at present, there are only researches focusing on targeted poverty alleviation which uses a single industrial programme such as photovoltaic power (Zhang et al., 2019), rural tourism (M. Liu et al., 2020) and so on. There are no in-depth studies on targeted industrial poverty alleviation mode in China using real cases and specific data. It is hoped that this study can provide beneficial inspiration for the solution of poverty problems in developing countries.

\section{METHODOLOGY}

\section{Data Collection}

The data used in this paper were collected from the local government of Yulin Township. The officers started official registration of poverty households by 2014 and recorded the relevant data from then on. Thus, the data covers years 2014 to 2019, with annual frequency. The first ("aggregate") part of the dataset covers all of the poverty households in Yulin Township. The data contains the following variables: number of poverty households, number of poverty population, percentage of poverty population, total spending by government, total income increase, and number of poverty households involved of each specific measure. The second ("individual") part of the dataset contains household-level data. 20 households have been selected at random. This part of the dataset includes average net income per person in the household for each year and the 
selection of the poverty alleviation measures made by the household.

\section{RESULTS AND DISCUSSION Entire Programme}

The main goal of this paper is to evaluate the effectiveness of the targeted industrial poverty alleviation programme described above. The objective of the programme is to eliminate poverty by 2020 . We do not have to track intermediate objectives because the programme is already reaching its end, so we can focus on this ultimate objective.
How should the programme impact be measured? While we cannot observe the perfect counterfactual (i.e. what would be the material situation of the poverty households in 2019 if the targeted poverty alleviation programme had not been instituted), we are willing to assume that the situation of the household would not change much compared to before the programme began in 2014. Consequently, we could obtain a good measure of how the programme has improved the incomes of the households by comparing their incomes in 2019 and 2014. This way, we could evaluate whether the ultimate objective of eliminating poverty has been achieved.

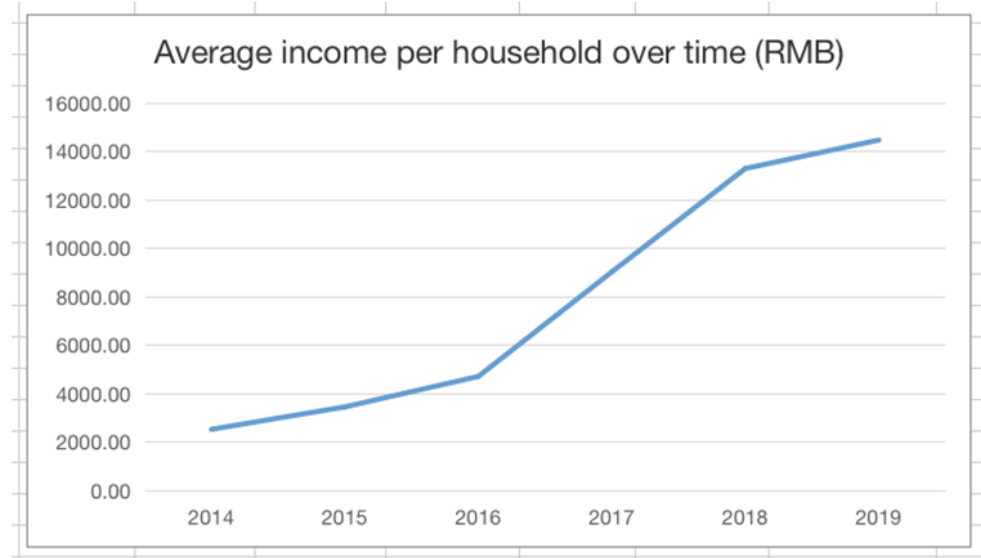

FIGURE 1. Average income per household (RMB) from 2014 to 2019

Figure 1 shows the average income per household over time for a subsample of selected 20 households mentioned above. The average income by the end of 2014 was 2,538.80 RMB. It increased relatively slow for two years and it reached 4,722.75 RMB in 2016. Then the rate of increase became faster since 2016, and by the end of 2018 the average income was $13,301.74$ RMB. After that, the average income rose further to $14,477.35 \mathrm{RMB}$ in 2019. This trend seems to suggest that the targeted industrial poverty alle- viation program significantly increased the incomes of the poverty population. Between 2014 and 2015, the rate of growth was quite slow because the method used was traditional and the targeted industrial poverty alleviation program has not been carried out. The relatively slower rate of growth in average income between 2018-2019 may be due to the fact that there were few poverty households left by then, and the program was not intended to raise further the income of non-poverty households.

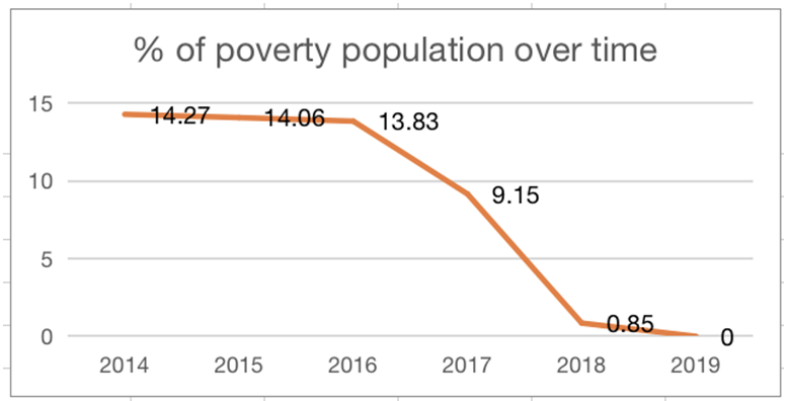

FIGURE 2. Percentage of poverty population in Yulin Township from 2014 to 2019

Figure 2 shows the percentage of poverty population over time. The trend resembles the mirror image of the trend in incomes. At the end of 2014, 2735 residents used to live in poverty. In 2014 and 2015, the percentage of population living in poverty was $14.27 \%$ and $14.06 \%$ respectively, so there had been little change. It dropped slightly to $13.83 \%$ by the end of 2016. It seems apparent that the percentage decreased sharply since 2016, when the government began the full-scale roll-out of the targeted industrial poverty alleviation programme. The percentage fell to $9.15 \%$ by the 
end of 2017 , and then to $0.85 \%$ by the end of 2018 . At this time, there were only 76 poverty households and 163 residents living in poverty. By the end of 2019, poverty in Yulin Township has been officially eliminated. This provides evidence that the targeted industrial poverty alleviation program has been effective in sharply reducing the size of the poverty population.

An additional consideration when evaluating poverty reduction programmes is its impact on the income inequality.
We consider it to be a desirable feature of the programme if it does not increase income inequality. In order to evaluate this aspect, we calculate the income inequality measure for each year starting from the year before the beginning of the programme. The measure of income inequality is the standard deviation of the households' incomes as the percentage of the average income per year. The analysis is again based on the data collected for the subsample of 20 households mentioned above.

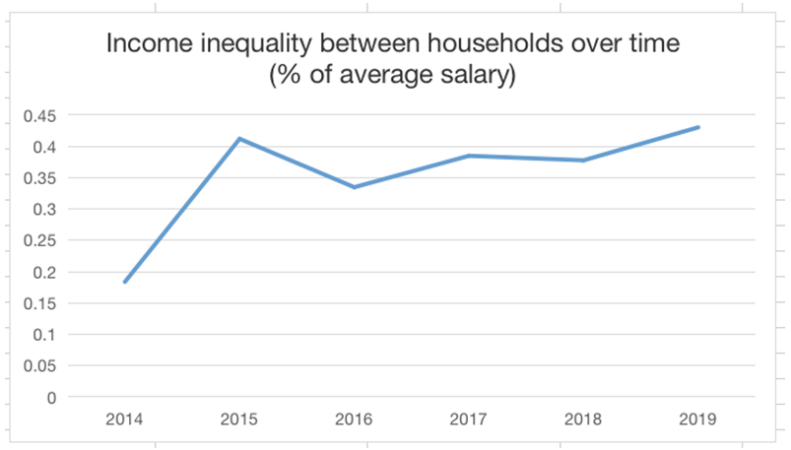

FIGURE 3. Income inequality between households over time (\% of average salary) from 2014 to 2019

Figure 3 shows that the income inequality between households over time has displayed several fluctuations. In 2014, this was about $0.18 \%$ which was the lowest in the evaluated period. Then there was a sharp increase to $0.41 \%$ in 2015 . From 2016 to 2018 , it varied between $0.3 \%$ to $0.4 \%$. And it finally increased to $0.43 \%$ in 2019 , which was the highest of these years. This shows that as poverty alleviation program was carried out, the income inequality has increased. However, the majority of the increase happened in 2014, which is before carrying out targeted industrial poverty alleviation, and since then it has remained relatively constant. Therefore, we may classify the increase in income inequal- ity associated with the targeted industrial poverty alleviation programme as mild.

\section{Individual Constituent Parts}

With the menu of options available to the residents to choose from, it is natural to ask which of the poverty alleviation measures could be considered the most effective. We propose three criteria to evaluate this: 1) the average extra income generated by each poverty reduction measure; 2) the universality of the measure expressed by the proportion of households we took it up; 3) the contribution of each measure to the overall improvement in income.

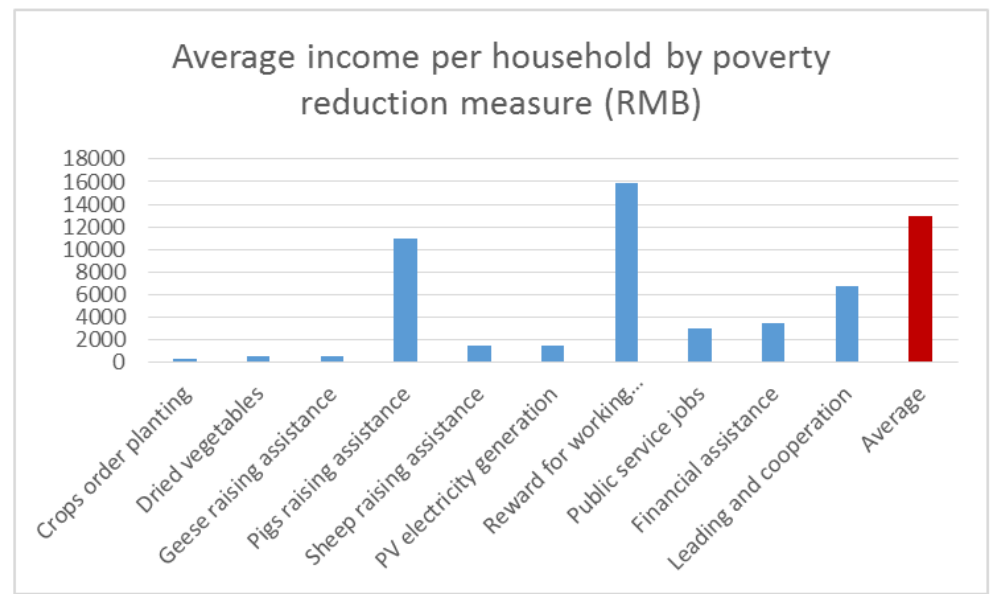

FIGURE 4. Average income per household by poverty reduction measures (RMB) 
Figure 4 represents the increase in average income per household by each measure. The average increase has been 12,717 RMB. The measure that brought the greatest increase in income was the reward for working and transportation subsidy (15,859 RMB). Pig raising assistance contributed to the second largest amount of increase in income, which is 11,000 RMB. These two measures are the only two measures that increased income by more than 10,000 RMB. Public service jobs and financial assistance each have raised incomes by about 3,000 RMB. The increases in income which resulted from the other measures have been all less than 2,000 RMB, and the smallest one has been 311 RMB resulting from crops order planting. However, as mentioned above, the increase in income is only one criterion by which the measure can be judged. In fact, for some measures the small increase in incomes may be due to the large number of households involved in this particular measure.

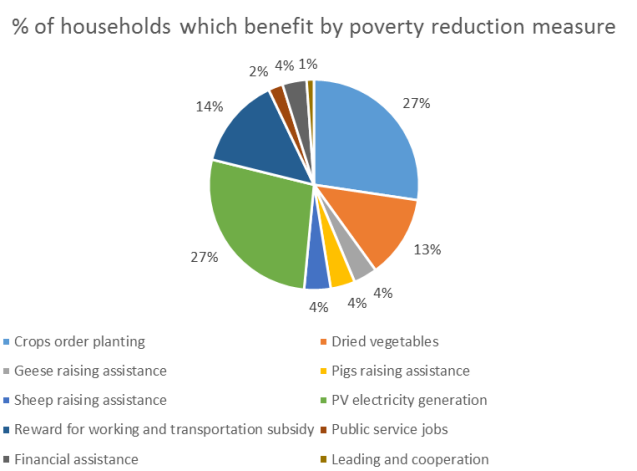

FIGURE 5. Percentage of households which benefit from poverty reduction measures

Figure 5 demonstrates the percentage of households who have benefitted from each measure. The highest percentage, $28 \%$ of poverty households have been involved in PV electricity generation. The second largest most popular measure has been crops order planting at $27 \%$, followed by the reward for working and transportation sub- sidy as well as dried vegetables at $14 \%$ and 13 , respectively. Sheep raising assistance, pigs raising assistance, geese raising assistance and financial assistance each benefited $4 \%$ of the households. The smallest number of households was helped by the public service jobs account at $2 \%$.

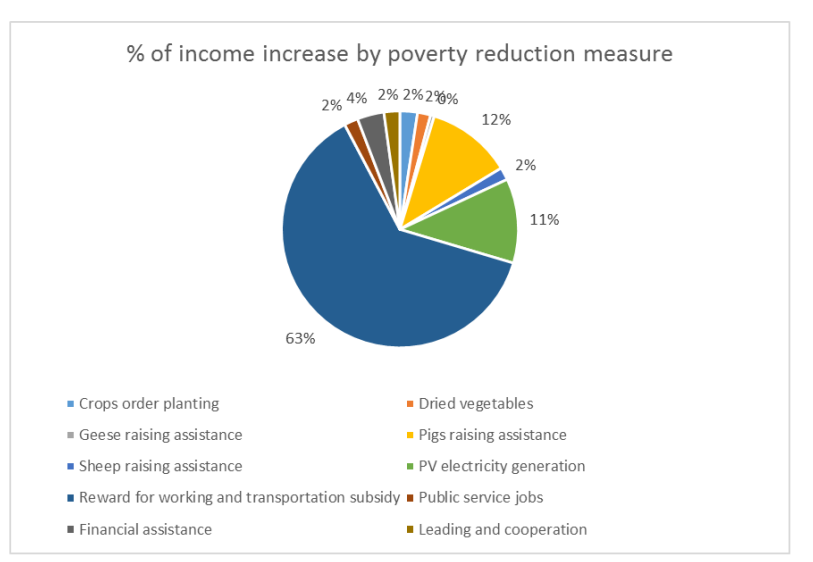

FIGURE 6. Percentage of income increase generated by poverty reduction measures

Figure 6 shows the percentage of the total income increase for all poverty households by each measure. At 64\%, the reward for working and transportation subsidy has had the greatest contribution. Pigs raising assistance and PV electricity generation both contributed $12 \%$ to the overall increase in income. Financial added $4 \%$ to the increase in income, while public service jobs, crops order planting, dried vegetables and sheep raising assistance added $2 \%$ each. Fi- nally, geese raising assistance only negligibly contributed to overall increase in incomes.

There are two main reasons for offering a menu of measures rather than just the most effective one: suitability and capacity. The former means that the most effective measure may not be suitable for everyone. Even if the most effective measure is the best one for a considerable part of the population, the goal of poverty alleviation is to reduce the overall 
number of poverty households to zero, so there must exist some suitable measure for every household. In particular, the measures which involve hard physical work (e.g., raising animals or commuting to work) may not be suitable for older people or people with disabilities. This is why one of the measures in the menu is PV electricity generation, which is deliberately targeted at those segments of the population (it is only available for people above 60 years or with disability).

Another reason why we could not rely just on one measure is that its capacity may be limited. Given the number of households in poverty, it would simply not be possible to lift everyone out of poverty through one measure alone. An example is leading and cooperation, which requires presence of a sufficiently large number of richer households.

So far, we also have not taken costs into account. The poverty reduction measures can be divided into two groups: those financed and not financed by the local government. In the first group (geese/pigs/sheep raising assistance, reward for working and transportation subsidy and public service jobs), the income generated by the measure is at least sufficient to cover the costs. In fact, for the first four measures, between 2.95-18.57 times as much income is generated as the measure costs the local government. The last measure is essentially a transfer from the government to the residents, so the multiplier is one.

In the second group, the government does not incur any costs directly; the measures are financed by other parties (companies or other individuals). Full cost-benefit comparison of the measures is impossible without knowing how much these measures cost the parties other than the local government. Also, the figures do not include administrative costs that cannot be directly attributable to a specific measure, so there might be a downward bias in them. However, even without knowing precisely the full costs of the poverty reduction programme, we were able to assess how successful it was in the goal of poverty reduction.

\section{CONCLUSION}

Overall, the targeted poverty alleviation measures seem to have been effective in reaching its ultimate goal of reducing poverty. Poverty in Yulin Township has been essentially eliminated by the end of 2019. This can be used as evidence that the targeted poverty alleviation programme has been effective. Average income per household has been increased considerably: the average income in 2019 is about 5.7 times the average income in 2014. Moreover, the rate of increase in average income has become faster since the start of the poverty alleviation programme. Additionally, the rate of decrease in poverty population has increased. This was shown to be particularly the case from 2017 to 2018, which was the second year of carrying out the targeted poverty alleviation programme. Looking at the programme in a granular manner, among the ten measures offered to the poverty households, it seems clear that the reward for working and transportation subsidy is the one that increased the incomes most notably, and did so for the highest number of poverty households.

In line with the conclusions of this paper, the targeted poverty reduction programmes have been lauded in 2017 in the Message for the Global Poverty Reduction and Development Forum by the U.N. Secretary-General Antonio Guterres: "Targeted poverty reduction strategies are the only way to reach those farthest behind and achieve the ambitious targets set out in the 2030 Agenda. China has lifted hundreds of millions of people out of poverty, and its experiences can provide valuable lessons to other developing countries.'

\section{LIMITATIONS AND RECOMMENDATIONS}

An important aspect of evaluating a poverty reduction programme is whether poverty returns upon the end of the programme. As the implementation of the targeted industrial poverty alleviation programme has not fully finished yet, it is impossible to evaluate this aspect of the programme right now. Another problem is the low number of households in the individual sub-sample, which may render it unrepresentative of the broader population. Since the total number of poverty households was more than one thousand, it is very likely that the situation of other households is not the same as the selected 20 households. As a result, conclusion deduced from the analysis of 20 households may unrepresentative and inaccurate. Finally, the targeted poverty alleviation programme has been carried out since 2016 and registration only started in 2014, which is not a long period till now. Therefore, the conclusions are based on only 6 years of data, which might accurately represent the effectiveness and influence of each measure.

Future research could focus on two aspects. First, it could investigate how the targeted industrial poverty alleviation programme in Yulin Township compares to the programmes in other provinces in China. This will help us to understand how Yulin Township's unique approach differs from other poverty alleviation programmes. Second, it could investigate the follow-on programme in Yulin Township: recently, the local government has published an idea of 'get rid of poverty but do not get rid of policies'. This means that although all residents have got out of poverty, 
the targeted poverty alleviation programme will continue to prevent them from getting back to poverty and help them to further increase their incomes.

\section{REFERENCES}

Dominique, P. M. (2019). Knowledge transfer models and poverty alleviation in developing countries: Critical approaches and foresight. Third World Quarterly, 40(7), 209-1226. doi:https://doi.org/10.1080/01436597.2019.1597340

Fan, S., Linxiu, Z., \& Xiaobo, Z. (2004). Reforms, investment, and poverty in rural China. Economic Development and Cultural Change, 52(2), 395-421. doi:https://doi.org/10.1086/380593.

Gustafsson, B., \& Wei, Z. (2000). How and why has poverty in China changed? A study based on microdata for 1988 and 1995. The China Quarterly, 164(6), 983-1006.

Hannum, E. (2003). Poverty and basic education in rural China: Villages, households, and girls' and boys' enrollment. Comparative Education Review, 47(2), 141-159. doi:https://doi.org/10.1086/376542.

Kim, H. (2016). Political correctness on David Mamet's oleanna. Journal of Advances in Humanities and Social Sciences, 2(3), 195-203. doi:https://doi.org/10.20474/jahss-2.4.1

Li, Y. (2019). Research on the rationality of precision poverty alleviation. Open Journal of Social Sciences, 7(4), 45-70. doi:https://doi.org/10.4236/jss.2019.74027

Li, Y., Su, B., \& Liu, Y. (2016). Realizing targeted poverty alleviation in China. China Agricultural Economic Review, 8(3), 443-454. doi:https://doi.org/10.1108/CAER-11-2015-0157

Liu, M., Feng, X., Wang, S., \& Qiu, H. (2020). China's poverty alleviation over the last 40 years: Successes and challenges. Australian Journal of Agricultural and Resource Economics, 64(1), 209-228. doi:https://doi.org/10.1111/1467-8489 .12353

Liu, Y., Guo, Y., \& Zhou, Y. (2018). Poverty alleviation in rural China: Policy changes, future challenges and policy implications. China Agricultural Economic Review, 10(2), 241-259. doi:https://doi.org/10.1108/CAER-10-2017-0192

Liu, Y., Liu, J., \& Zhou, Y. (2017). Spatio-temporal patterns of rural poverty in China and targeted poverty alleviation strategies. Journal of Rural Studies, 52(5), 66-75. doi:https://doi.org/10.1016/j.jrurstud.2017.04.002

Luk, T. C. (2000). The politics of poverty eradication in rural China. China Review, 5(7), 509-527.

Malthus, T. R. (1980). An essay on the principle of population. New York, NY: Penguin Classics.

Meng, L. (2013). Evaluating china's poverty alleviation program: A regression discontinuity approach. Journal of Public Economics, 101(6), 1-11. doi:https://doi.org/10.1016/j.jpubeco.2013.02.004

Myrdal, G. (1991). The challenge of world poverty: A world anti-poverty program in outline. New York, NY: Random House Trade Paperbacks.

Nima, G. (2019). Measures and safeguards to realize stable poverty alleviation in contiguous destitute areas based on human capital development: A case study of Xialatuo village. Open Journal of Social Sciences, 7(4), 56-70. doi:https://doi.org/ $10.4236 /$ jss.2019.74007.

Okpala, O. R., Omojuwa, Y., Elenwo, C. G., \& Opoko, P. A. (2017). Sustainable urbanization: Investigating problems encountered in uncontrolled urban growth in Nyanya-A suburb of Abuja, Nigeria. International Journal of Humanities, Arts and Social Sciences, 3(1), 13-19. doi:https://doi.org/10.20469/ijhss.3.20003-1

Piazza, A., \& Liang, E. H. (1998). Reducing absolute poverty in China: Current status and issues. Journal of International Affairs, 5(8), 253-273. doi:https://doi.org/10.2307/24357822

Sen, A. (2001). Development as freedom. Oxford, UK: Oxford University Press.

Short, C. (2002). Poverty eradication and social integration: The position of the UK. International Social Science Journal, 51(162), 467-472. doi:https://doi.org/10.1111/1468-2451.00217

Wang, J., Chen, Y., \& Yan, M. (2016). Research on the targeted measures of poverty alleviation and its innovative ways in China. Bulletin of Chinese Academy of Sciences, 31(3), 289-295. doi:https://doi.org/10.16418/j.issn.1000-3045.2016.03.003

Xu, l., Zhang, Q., \& Shi, X. (2019). Stakeholders strategies in poverty alleviation and clean energy access: A case study of China's PV poverty alleviation program. Energy Policy, 135(6), 56-78. doi:https://doi.org/10.1016/j.enpol.2019 .111011. 
Zhang, J., Zhang, Y., Cheng, M., Yu, N., Wei, X., \& Zhang, Z. (2019). Impact of information access on poverty alleviation effectiveness: Evidence from China. IEEE Journal, 5(7), 567-579. doi:https://doi.org/10.1109/ACCESS.2019.2946652

Zuo, C. (2019). The evolution of china's poverty alleviation and development. Beijing, China, Social Sciences Academic, 5(7), 56-70. doi:https://doi.org/10.1007/978-981-13-1690-6. 